\title{
Emerging market financial services development: the case of leasing in Poland and China
}

\section{Piotr Marek Jaworski^ and Simon Gao}

The Business School,

Edinburgh Napier University,

Criaglockhart Campus,

Edinburgh EH14 1DJ, Scotland UK

E-mail: p.jaworski@napier.ac.uk

E-mail: s.gao@napier.ac.uk

*Corresponding author

\section{Adam Sliwinski}

Institute of Insurance, Warsaw School of Economics, al. Niepodleglosci 162, 02-554 Warszawa Poland

E-mail: asliwin@sgh.waw.pl

\begin{abstract}
The aim of this paper is to present Polish and Chinese developments in this area in the period of 1999-2009 for the former and 2005-2008 the latter and then to compare both markets for 2007 and 2008 using different metrics. The time horizon is limited due to the lack of Chinese data. The results show that both economies used leasing to finance ongoing business and both markets have many common features. The results show also that although the Chinese leasing market is less developed, it catches up with the more developed Polish counterpart.
\end{abstract}

Keywords: financial services; leasing; innovation; learning; Poland; China.

Reference to this paper should be made as follows: Jaworski, P.M. and Gao, S. (xxxx) 'Emerging market financial services development: the case of leasing in Poland and China', Int. J. Innovation and Learning, Vol. X, No. Y, pp.000-000.

Biographical notes: Piotr Marek Jaworski is a Lecturer of Economics at The Business School, Edinburgh Napier University in Edinburgh. Previously, he worked in Britain at School of Slavonic and East European Studies of University College London and Birkbeck College and in Poland at Warsaw School of Economics and Ministry of Finance. He graduated from Warsaw School of Economics (MA), London School of Economics and Political Science (MSc) and University of Minnesota (MBA). His PhD thesis on economics of pension systems, written at the Warsaw School of Economics, was awarded with first prize for the Best Polish Thesis by the BISE bank.

Simon Gao is a Professor of Accounting and Finance at Edinburgh Napier University and has led the research development of accounting and finance since 1999. He holds a PhD from Erasmus University Rotterdam and an MA and a BA from Xian Jiaotong University of China. He has been the UK 
Academic Director of the joint Masters programme based at Southwestern University of Finance and Economics in Chengdu, China. He is the Research Leader of the Edinburgh Institute of Accountancy and Financial Services, and the school's PhD Programme Coordinator, as well as a Visiting and Guest Professor at five universities in China.

Adam Sliwinski is a Senior Lecturer at Warsaw School of Economics, where he received his doctoral degree in 2001. He was a Postdoctoral Fellow at University College London and Visiting Researcher at Cass Business School City University. He has been a Visiting Lecturer at the Edinburgh Napier University and completed Ignite 2012 training at Judge Business School, Cambridge University. His main area of research interests are risk management and empirical aspects of finance and insurance. He has business experience gathered cooperating with a number of international insurers and financial institutions.

\section{Introduction}

Throughout centuries innovation was a factor of success for many companies. Its role is even more important now in the times of during economic downturn: it serves as a key factor not only of recovery but also of subsequent growth. The European Union The Community Framework for State Aid for Research and Development and Innovation (Official Journal of the European Union, no. C 323/1 of 30.12.2006) defines it as “...the implementation of a new or significantly improved production or delivery method (including significant changes in techniques, equipment and/or software)". However, such activity requires funding and leasing could be seen as a major source of its funding. Therefore, a study on leasing development in its early and intermediate stages relates also to the area of innovation by both creation of new innovative means of finance and covering costs of equipment used to create new methods, processes, technologies. This could contribute to creation and improvement of the organisational learning process.

Leasing can be defined using different perspectives from legal, accounting, financial, marketing to economic, macro as well as micro (Gao, 1999). International Finance Corporation study on leasing in development economies (1996) defines leasing as a contractual agreement to use an asset owned by a leasing company (lessor) by another party (lessee) in exchange for a periodic payment. This definition includes four important characteristics identified by Gao (1999): a separation of ownership form economic use, a series of payments involved, a period in which the ownership is separated from the right to use and the existence of an asset that is the base for such a contract. This makes leasing together with asset-based lending an effective tool protecting the asset in case of default payment (Berger and Udell, 2006; Beck and Demirguc-Kunt, 2006). Also, leasing allows flexible allocations of production assets not limited by the credit history of the lessor but by feasibility of projects, for which the assets are used. 
Figure 1 Growth of leasing in the UK, Ireland, Czech and Slovenia, 1988-1996

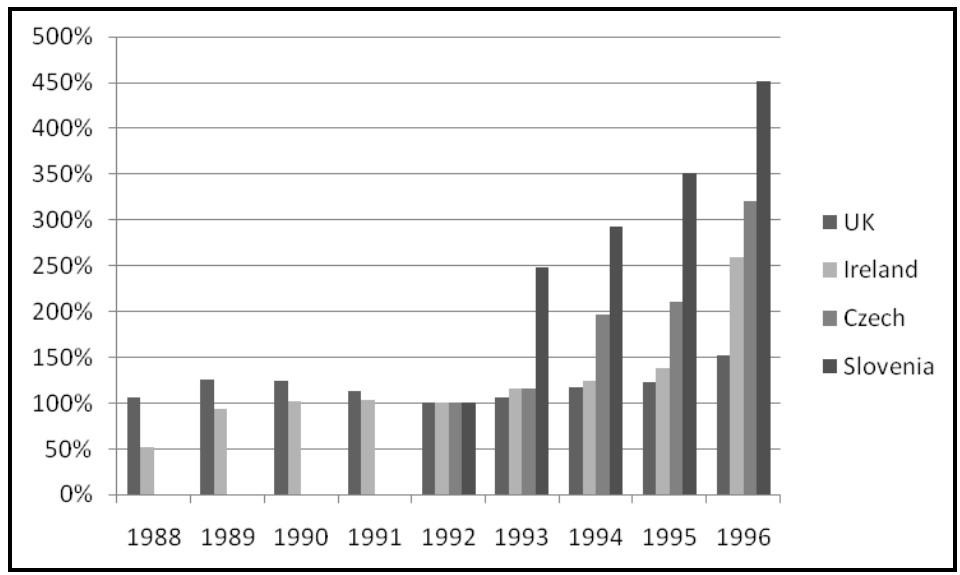

Source: Calculated from data of the European Federation of Leasing Company Associations

Figure 2 Growth of leasing in Italy, Portugal and Spain, 1988-1996

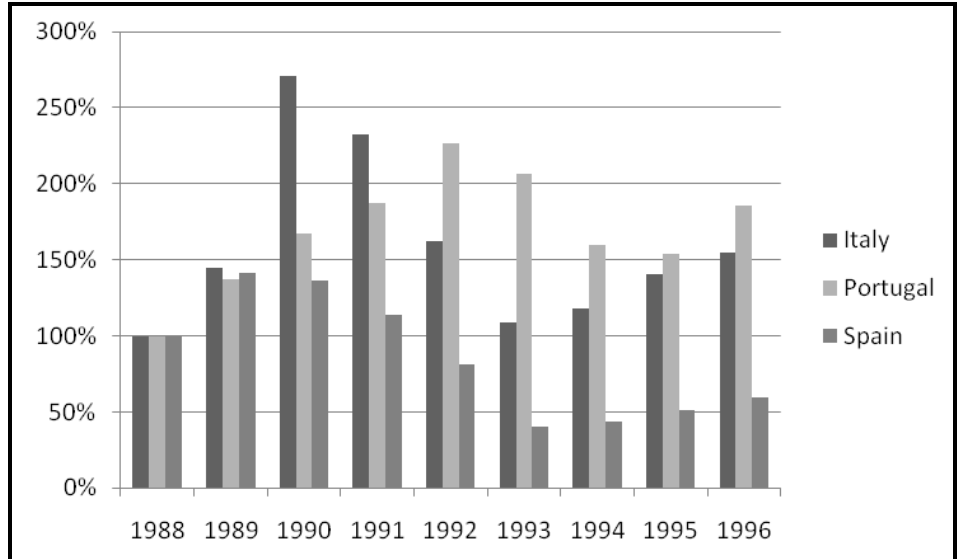

Source: Calculated from data of the European Federation of Leasing Company Associations

It was estimated that in developed European countries leasing occupied 15-30\% of all new investments in plant and equipment (Gao, 1999). In 2009 leased assets reached $26.9 \%$ and $56.5 \%$ of the total investment in equipment in the USA and UK respectively (Investor, Euromoney Institutional, 2009). While strong growth of leasing was observed in many markets since 1992 as shown in Figure 1, the development of leasing was largely dependent on the economic conditions and business environments of a country. For example, the UK has witnessed very strong dependence of leasing on the economic conditions: the crises of the beginning of nineties had adverse effects on the total amount of new leased assets and equipment. This is also very clear when other EU economies are included in the picture (see Figure 2). This tendency is natural in the times of economic 
slowdown as companies lessen their demand for leasing and delay purchase of fixed assets whenever possible (Haynes, 2009).

Furthermore, countries like Estonia, Czech Republic, Slovakia, Hungary together with Latvia and Bulgaria occupy first places in rankings of leasing as a share of GDP, with the latter ranging from 3.75\% to 8.66\% (Investor, Euromoney Institutional, 2004, 2009). Leasing in the transition economies of Central and Eastern Europe and China played an important role in their economic transformation. In Poland, for example, leasing was used as one of the privatisation tools in the 1990s (Gao, 1995, 1999).

Previous studies of leasing were mostly based on a single economy, focusing on the finance nature of leasing from a business perspective. The aim of this paper is to compare the leasing developments in Poland and China with a view to identifying the differences and similarities of the leasing industry between the two emerging economies. Such a comparison would enhance our understanding of the function of leasing and the development of leasing in transition economies. Specifically, this paper uses seven parameters, including leasing as a share of GDP, leasing as a share of investment, annual growth of leased equipment value, total growth of leased equipment value, a share of machinery in total leasing, a share of printing machines in total leasing, and a share of medical equipment in total leasing to compare leasing between Poland and China in terms of its development and contributions to the economy.

Poland and China have much common in their economic system and transitions as both countries were formerly centrally-planned economies, and the economic reforms have transformed both countries to relatively developed market-based economies. Both Poland and China are classified as developing economies with the former belonging to upper middle income group while China being lower middle income. ${ }^{1}$ Small- and Medium-sized Enterprises (SMEs) play an important role in both economies. As of the end of June, 2007, more than 42 million SMEs and microenterprises were registered with China's Administration of Industry and Commerce (AIC) and formally registered SMEs represent more than $99 \%$ of all enterprises in China, accounting for over $55 \%$ of GDP and over $62 \%$ of imports and exports, and contributing more than $46 \%$ of tax revenues to the national economy [SME Department of the National Development and Reform Commission (NDRC), 2008]. In Poland the average share of SMEs employment in total labour force amounted to $61.81 \%$ for the $1990-1999$ period, while its share in GDP in the same time was equal to $48.73 \%$. The respective data for the UK were $56.42 \%$ and 51.45\% (Ayyagari et al., 2007).

This paper is organised as follows. The next section provides a literature review considering the function of leasing and factors influencing the growth of leasing. Section three describes the backgrounds and general developments of leasing in Poland and China. Section four explains the research method and models. Section five presents the results of comparative study based on the models and concludes the paper.

\section{Literature review}

The extant literature has examined the function of leasing comparing with debt finance and identified a number of factors that influence the development of leasing. It has been widely accepted that leasing and debt are related to each other if the economic perspective is undertaken as both are means of financing productive assets and industrial equipment. Deloof et al. (2007) point out that leases and debt are fixed, contractual 
obligations that reduce the firm's debt capacity. The literature shows that leases and corporate debt are substitutes in case of both large organisations and SMEs (e.g., Huang and Yildirim, 2006; Deloof et al., 2007; Yan, 2006; Beattie et al., 2000; Lasfer and Lewis, 1998; Adedeji and Stapleton, 1996; Nguyen and Sharpe, 1995; Krishnan and Moyer, 1994; Lewis and Schallheim, 1992). While Huang and Yildirim (2006) observe that the substitution ratio increases as debt maturity increases, Lasfer and Lewis (1998) find that the substitutability of debt and lease contracts for large companies was largely driven by taxes.

Comparing leasing and debt, the finance literature often suggests leasing to be a preferred choice as it lacks a sophisticated legal system needed for asset-based lending (Berger and Udell, 2006). This is important for the markets with an absence of well-developed institutions because leasing can be useful in facilitating greater access to finance (SME's in Europe, 2003), particularly for SMEs. Nguyen and Sharpe (1995) show that firms facing high costs of external funding can decrease it by using leasing, which in effect makes low rated firms more likely to use leasing. As SMEs face more problems of asymmetric information, making them less credible in debt financing, Deloof et al. (2007) claim that leasing will play more important role in their external financing.

Taxes have been identified as one of the major factors influencing the usage of leasing (Gao, 1999; Graham et al., 1998; IFC, 1996; Nguyen and Sharpe, 1995). The International Finance Corporation (1996) note that leasing has tax advantages if the lessor and lessee face different marginal tax rates. Nguyen and Sharpe (1995) show that tax rate and leasing propensity is negatively correlated. Other factors influencing the usage of leasing have also been recognised, including costs of financial distress and government regulation (Graham et al., 1998), asymmetric information (Deloof et al., 2007; Krishnan and Moyer, 1994), cultural acceptance (Gao, 1999), and insitutional developments (Berger and Udell, 2006). For example, Krishnan and Moyer (1994) argue that the presence of asymmetric information can be overcome by leasing. Leasing is even better than secured debt, as the lessor has superior claims over secured lenders, therefore leasing reduces bankruptcy costs.

Amembal (2009) defines four stages of leasing evolution: non-existent, nascent, emerging and mature with the majority of countries belonging to the emerging stage and Australia, the UK and the USA being at the mature state. He also identifies six phases of leasing cycle:

1 rentals

2 'simple' finance lease

3 ‘creative’ finance lease

4 operating lease

5 new products

6 maturity.

Rentals phase is existent in almost all countries in the world. It is characterised by its short term, full-service nature implying that ownership responsibilities lay with the side operating the rented asset, which at the end of the agreement is returned to the owner. In the second phase the leasing is merely a financial instrument with the lessee intending eventually to own the asset. The third stage is characterised by the highest rate of growth; 
here the lessor starts to extend the range of end-of term options, offering the lessee for example purchase or renewing the contract using the residual value. Evolution to the fourth phase is brought about by intense competition and international transfer of technology with bundling of services and one-stop shopping. In phase five new products are brought in: securitisation together with venture and synthetic leases appear. The range of end-of-term options also widens even more. The final phase brings substantial consolidation; it also flattens penetration making the share of capital formation utilised by leasing constant.

The role of leasing in financing business assets and equipment in a national economy has been widely recognised in developed economies. It is estimated that the European Federation of Leasing Company Associations (Leaseurope) represents approximately 96\% of the European leasing market. In 2008, 330 billion euros of new leasing volumes were granted by the firms represented through Leaseurope's members, contributing to financing on average $18 \%$ of total European investment. While leasing has been developed in many developing economies, the function of leasing and its role in these economies were under researched.

\section{Leasing in Poland and China}

\subsection{Leasing in Poland}

Leasing in Poland started at the beginning of 1990s after the start of transition to a free market economy. Initially leasing was not regulated in Polish law and it was defined in Civil Code only in 2000. However, in practice tax law contained provisions allowing this institution to exist in economic transactions. Main assets leased were vehicles, machines and equipment used for economic activity (Szafarowska, 2008). In the last decade of 1999-2009, the annual value of leased equipment was more than quadrupled in real terms if the highest (2007) and the lowest (2001) values are compared. Year 2000 brought also some disturbances to the market as some leasing firms went bankrupt. This made Polish Banking Association to tighten rules on refinancing (Martowski, 2003). However, the last two years also recorded a substantial drop, which can be attributed to the financial crises, which is similar although not so drastic to drop recorded in 2001-2002, as the crises then was much milder than the current one as shown in Figure 3.

While it experienced a high growth at the beginning, the leasing market was relatively small with relatively high risk. This was partially caused by a lack of a sound regulatory environment, and particularly the absence of the leasing law together with the unstable tax system. Rules across different areas of legislations are not compatible with each other as the definitions or treatments are different in the Civil Code, Income Tax Act, VAT Act and Accounting Act. This, together with arbitrary interpretation provided by governmental institutions, increases every kind of risk (Szafarowska, 2008). Also, a lack of medium to long-term finance available and the poor information flow system were attributed to the slow development of leasing. Gao $(1995,1999)$ also notes that a lack of local managers with experience in accounting, finance and other western business practices in the process of economic transformation from the centrally planned system to a free market economy was a major factor hampering the growth of leasing. 
Figure 3 Annual and total growth leased equipment value, Poland in real terms, 1999-2009

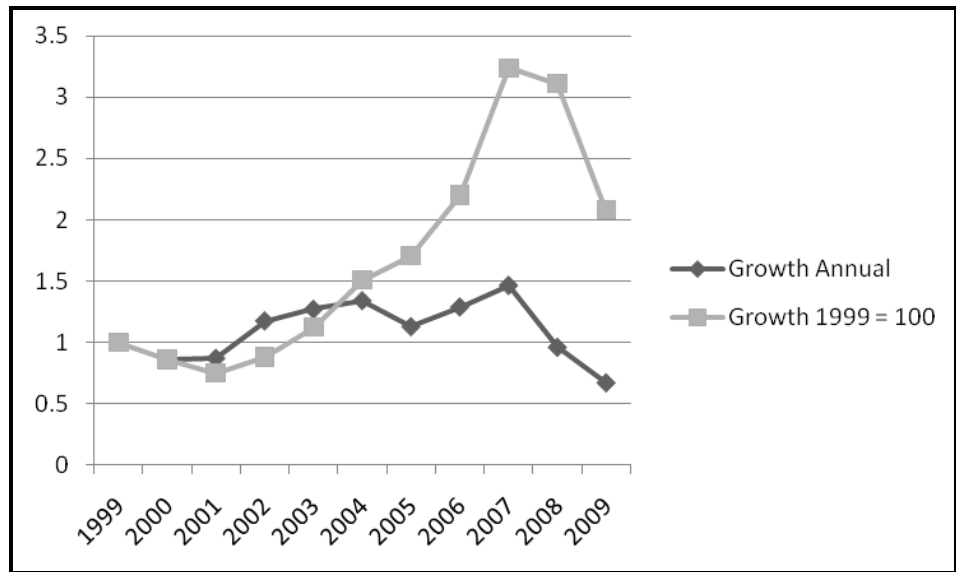

Source: Calculated from data of the Polish Leasing Association, Polish Central Statistical Office and the World Bank

In the relative terms the growth of leasing was also impressing: in relation to the GDP the value of leasing increased from its lowest level of $0.83 \%$ in 2001 to the highest level of $2.71 \%$ in 2007 and in relation to a total investment from $5.2 \%$ in 2002 to $16.7 \%$ in 2007, as shown in Figure 4. Again in this case the latest data show a decrease but it seems to be a result of the economic slowdown.

If market concentration is concerned, except for the financial slowdown, the combined share of three, five and ten biggest leasing providers, N3, N5 and N10, are quite stable and oscillate near 30\%, 45\% and 70\% respectively (see Figure 5).

Figure 4 Leasing as a share of GDP and investment, Poland, 1999-2009

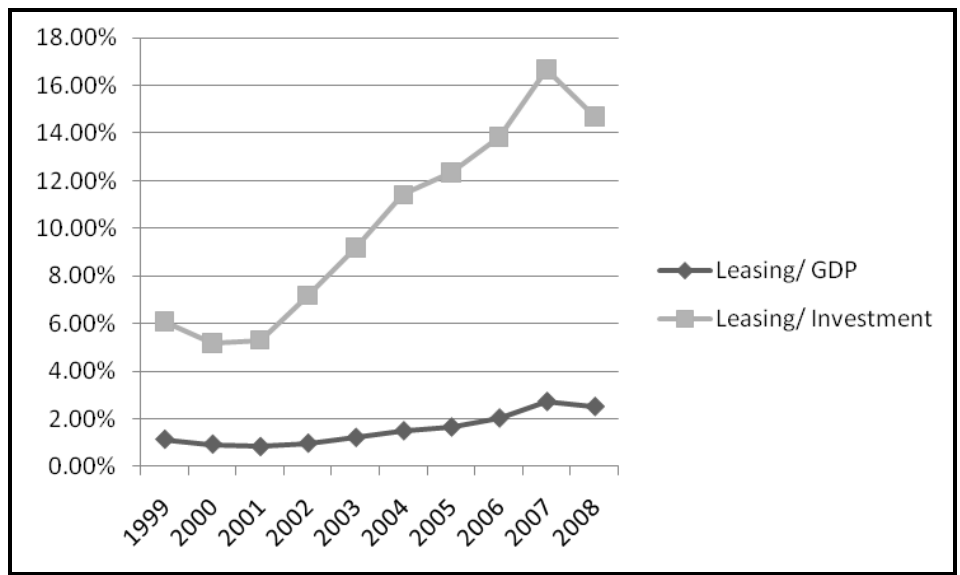

Source: Calculated from data of the Polish Leasing Association, Polish Central Statistical Office, and the World Bank 
Figure 5 Leasing market concentration, Poland, 1999-2009

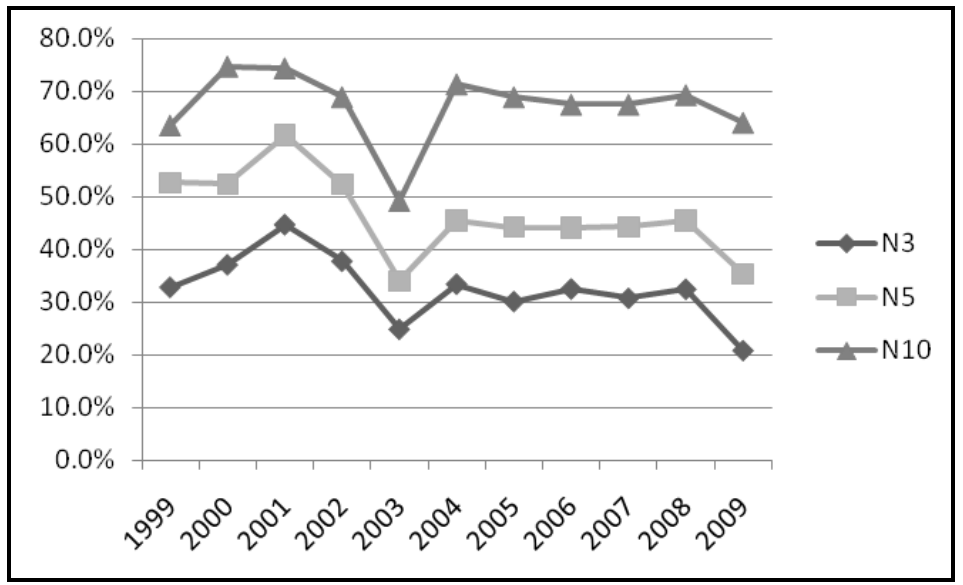

Source: Calculated from data of the Polish Leasing Association

The majority of leased assets are movables; their share stabilised at over $90 \%$ in the last four years. A major characteristic feature of the Polish market is high share of vehicles in the assets leased: it ranged in the first decade of new millennium between $40 \%$ to more than $70 \%$ (see Figure 6). The reasons for such volatility could be attributed to changes in tax treatment of passenger cars leasing. In case of leasing of machinery there could be observed an upward trend increasing its share from its minimum level of $20 \%$ in 2004 to almost 35\% in 2009.

Figure 6 Share of vehicles and machinery in total leasing, Poland, 1999-2009

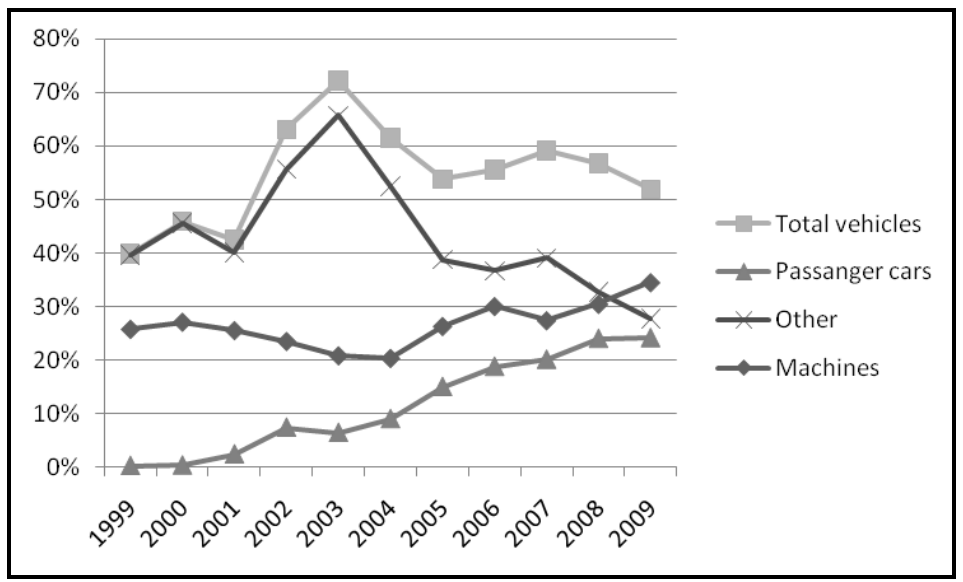

Source: Calculated from data of the Polish Leasing Association 


\subsection{Leasing in China}

According to Dipchand (1993), China being a socialist economy did not use leasing in the period of 1949-1979 as the majority of assets were financed and owned directly by the state. The turning point was 1979 with the policy of Open Door providing for a larger degree of economic activity, which was not strictly regulated in the limits of a centrally planned economy. First ventures were undertaken by the foreign companies entering the Chinese market, like Goodyear Printing Press from Hong Kong entering Shenzhen with HK \$13 million of machinery leased by Japan Oriental Leasing branch in Hong Kong (Dipchand, 1993). This was followed by establishing of the first Chinese leasing company in 1980, whose 50\% was owned by Japan Oriental Leasing (Hiato, 1986).

By 1985 there were 32 leasing companies operated in China with turnover of $\$ 700$ million annually, mostly joint ventures (Dipchand, 1993). This form was a result of difficulties on the market related to time-consuming approval procedure, uncertain guarantees for the security of leased assets uncertainty of the availability of foreign exchange and the lack of the legal framework; the investment was, however, not motivated by an immediate profit but by the possibility of gaining knowledge of the market (Sharon, 1989). There were also Chinese companies without foreign participation established with the first one being Chinese Lease Company Ltd. set up in August 1981.

Table 1 Chinese leasing legislation, 2000-2009

\begin{tabular}{|c|c|c|}
\hline Date & Act & Issuing Institution \\
\hline $\begin{array}{l}30 \text { June } 2000 \\
\text { Revised and improved } \\
\text { March } 2007\end{array}$ & $\begin{array}{l}\text { Measures for the Administration of } \\
\text { Financial Leasing Companies }\end{array}$ & The People's Bank of China \\
\hline 18 January 2001 & $\begin{array}{c}\text { Accounting Standards for Business } \\
\text { Enterprises - Leases }\end{array}$ & The Ministry of Finance \\
\hline 27 November 2001 & $\begin{array}{l}\text { Accounting Systems for Business } \\
\text { Enterprises, which is applicable to } \\
\text { leasing companies }\end{array}$ & The Ministry of Finance \\
\hline 14 August 2001 & $\begin{array}{l}\text { Interim Measures for the } \\
\text { Examination and Approval of } \\
\text { Foreign-funded Lease Companies }\end{array}$ & $\begin{array}{l}\text { The Ministry of Foreign Trade and } \\
\text { Economic Cooperation }\end{array}$ \\
\hline 15 January 2003 & $\begin{array}{l}\text { Notice about Some Issues } \\
\text { Concerning Business Tax Practice } \\
\text { (definition of tax base for leasing } \\
\text { companies) }\end{array}$ & $\begin{array}{l}\text { The Ministry of Finance and the } \\
\text { State Administration of Taxation }\end{array}$ \\
\hline 22 October 2004 & $\begin{array}{c}\text { Notice on Taxation on Relative } \\
\text { Issues concerning undertaking } \\
\text { Financing Leasing }\end{array}$ & $\begin{array}{c}\text { The Ministry of Commerce and } \\
\text { the State Administration of } \\
\text { Taxation }\end{array}$ \\
\hline 3 February 2005 & $\begin{array}{l}\text { Measures for the Administration of } \\
\text { Foreign-capital Lease Industry }\end{array}$ & The Ministry of Commerce \\
\hline 18 August 2009 & $\begin{array}{l}\text { Announcement on Bond Issues by } \\
\text { Leasing Companies }\end{array}$ & $\begin{array}{c}\text { The People’s Bank of China and } \\
\text { China’s Banking Regulatory } \\
\text { Commission }\end{array}$ \\
\hline
\end{tabular}

Source: Research In China (2008) 
By the 1990 there was something about 400 leasing companies independent from the central administration established by the local governments and enterprises (Dipchand, 1993). At that time the leasing industry was in the state of early infancy and was very closely related to central planning principles as the leasing assets had to be included in the State physical plan and the joint venture Chinese partners were mostly state owned enterprises lacking of efficiency. In addition, there was a severe short of qualified local staff resulting from the long existing central planning system (Dipchand, 1993).

The first legal acts issued by the government on leasing appeared only in the middle of nineties of last century: on 28th May 1996 Supreme Court issued Rules on the Relevant Issues Concerning Hearing of Financial Leasing Contract Disputes and 1st October 1999 Contract Law was supplemented with definitions of financial and operating leasing (Research In China, 2008). These two legal documents paved the way for further legislation, which is presented in Table 1.

The legal structure developed in China, however, has serious flaws: there are three independent authorities regulating three separate market segments. The law divides the leasing companies into three groups: non-banking financial leasing companies, regulated by the People's Bank of China, non-financial leasing companies regulated by the State Bureau of Internal Trade and overseas leasing companies operating in China regulated by the Ministry of Foreign Trade and International Cooperation. Consequently the rules governing the market are different for all three segments and practically discriminate national companies (Research In China, 2008).

Figure 7 Leasing as a share of GDP and investment in real terms, China, 2005-2008

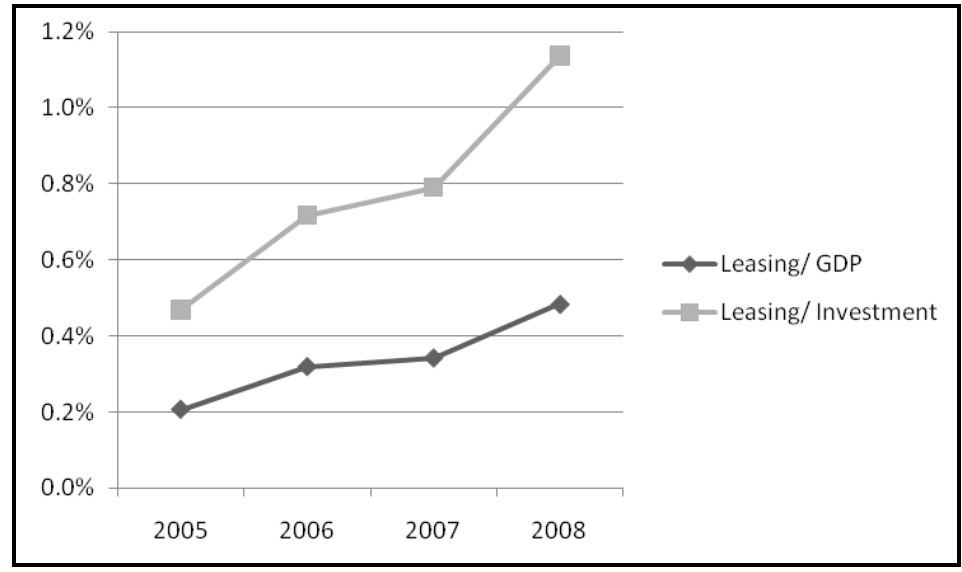

Source: Calculated from data of Research In China, 2008 and the World Bank

The same situation could be observed if taxation is concerned: the rules favour international players. The tax rules and treatments are also inconsistent, which creates extra uncertainty for leasing companies to plan their economic activities. Furthermore there is too much regulation and control provided to the market (Research In China, 2008). 
Figure 8 Annual and total growth leased equipment value in real terms, China, 2005-2008

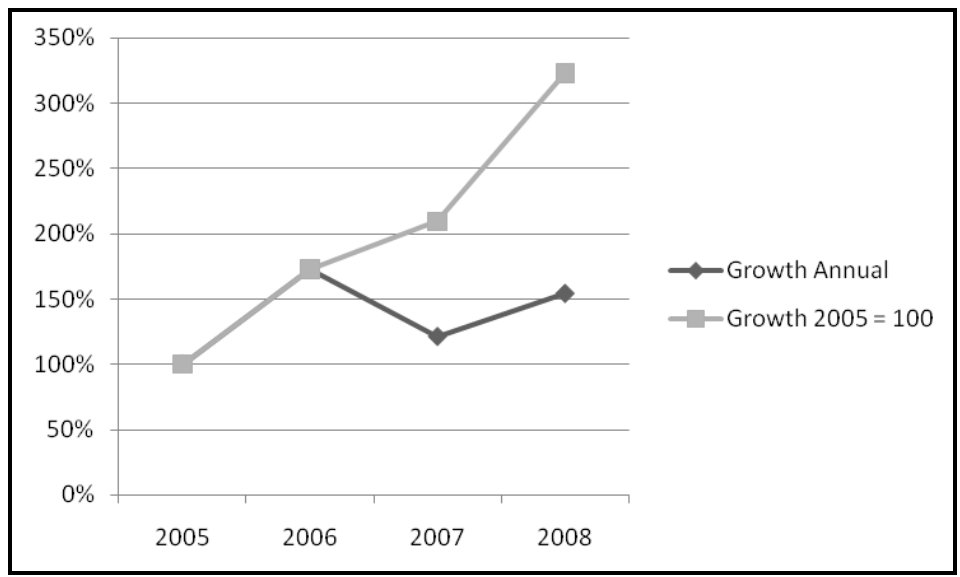

Source: Calculated from data of Research In China, 2008 and the World Bank

Overall, leasing market in China after three decades of operation is still tiny comparing with other instruments of financing investment: its share in total investment rose from $0.47 \%$ in 2005 to $1.14 \%$ in 2008 but still plays marginal role in the process of capital formation. Also the share of leasing in GDP rose in those years, however, in 2008 constituted only $0.48 \%$ of the national product, as shown in Figure 7 . With such marginal shares it is not surprising that the rates of growth are very high (see Figure 8).

Table 2 Leasing as a share of total investment in Poland and China, 2005-2008

\begin{tabular}{llll}
\hline$\#$ & Year & Poland & China \\
\hline 1 & 2005 & $12.3 \%$ & $0.47 \%$ \\
2 & 2006 & $13.8 \%$ & $0.72 \%$ \\
3 & 2007 & $16.7 \%$ & $0.79 \%$ \\
4 & 2008 & $14.7 \%$ & $1.14 \%$ \\
\hline
\end{tabular}

Source: Calculated from data of Research In China, 2008, the World Bank, The Polish Leasing Association and National Statistic Office of Poland

\subsubsection{Comparison of the developments of the Polish and Chinese leasing markets}

While a detailed comparison of the two markets is difficult to perform, on the whole both markets are characterised by substantial growth. The Polish market seems to be much more developed as shown in Table 2. The role leasing plays in financing the capital formation was much more important in the Polish case over the period 2005 to 2008, for which we have reliable data in the Chinese case (see Table 2). Figure 4 reveals that leasing share in the Polish GDP was equal to more than 2\% in 2008, which was more than four times higher than in China $(0.48 \%)$ shown in Figure 7 . However, the low starting level makes logical much stronger growth of the Chinese market, which in the period of 2005-2008 grew on average by 34\% annually while the Polish growth was equal only to $7 \%$. 
The growth of China suggests that the leasing market would play much more important role in financing new investment. Then the question posed is whether it shows signs of catching-up with market, which to some extent, starts from a similar level of socio-economic conditions. Therefore, in order to compare the relative difference between the two markets a comparative analysis is carried out. It focuses on the comparison of different parameters of the markets treated as dimensions, analysis of variances and averages for the whole period and taxonomy methods. The rationale for the last methods is the fact that they are useful in comparative analysis of multidimensional objects: utilising specific measures applied to different dimensions of the objects based on different criteria. The result enables to classify objects by compiling their rankings. Furthermore, they also provide an analysis of objects from both holistic and individual perspectives: differentiation and similarity of objects can be seen through a number of criteria, and accordingly the variation and distance between the objects as a whole set of dimensions and between the dimensions separately can be identified (Michalski and Golebiowska, 1996).

Berger and Udell (2006) point out that development of institutions over time could positively contribute to the development of leasing, especially in the case of competitive financial systems involved with foreign banks. It can be argued that the development of leasing in both Poland and China was largely attributed by the advance of its financial systems with the participation of foreign banks and financial institutions.

\section{Research method: measures and models}

\subsection{The measures used}

In this study two groups of measures are used: measuring the distance and measuring similarity. The distance measures included three metrics: Euclidean, Manhattan and Minkowski. Euclidean metric (L2 norm) is the most popular and common one: the differentiation of the objects' dimensions is defined as geometric distance between them. For quantification the following formula is utilised:

$$
d_{i, p}=\left(\sum_{j=1}^{p}\left(z_{i j}-z_{p j}\right)^{2}\right)^{\frac{1}{2}}
$$

where $d_{i p}$ denotes the distance between the objects $i$ and $\mathrm{p}$ and $z_{i j} z_{p j}$ the values of dimensions (parameters) $j$ of object $i$ and p respectively.

Manhattan metric (L1 norm) is different from Euclidean metric in one respect: instead of the square rooting of the squares of a sum of the differences, it uses absolute values. The formula takes the following way (all the parameters are the same as in the case of Euclidean metric):

$$
d_{i, p}=\sum_{j=1}^{p}\left|z_{i j}-z_{p j}\right|
$$

Minkowski metric (Ln norm) could be seen as a general form, from which both other metrics could be derived. Its formula is as follows: 


$$
d_{i, p}=\left[\sum_{j=1}^{p}\left|z_{i, j}-z_{p, j}\right|^{n}\right]^{\frac{1}{n}}
$$

where $n$ could be any number chosen; in our case it is 7 : the number of dimensions that we have the values for both markets.

\subsection{Taxonomy measures}

The measure $\mu$ describing the degree of similarity between dimension structures of the two objects is defined with the following equation:

$$
\mu_{i, p}=\frac{z_{i}{ }^{\circ} z_{p}}{\left|z_{i}\right|\left|z_{p}\right|}
$$

where $z_{i}{ }^{\circ} z_{p}$ denotes the scalar multiple of vectors $z_{i}$ and $z_{p}$ containing all dimensions of the particular objects and $|z|$ the length of the vectors. This means that the value of the $\mu$ is between -1 and 1 as the scalar multiple is a cosine of the angle between the vectors.

The measure of similarity of objects' dimensions $d^{*}(i, p)$ is defined by the following equation:

$$
\begin{aligned}
& d^{*}(i, p)=1-\frac{1}{2 \sqrt{k n}} * d(i, p), \\
& 0 \leq d^{*}(i, p) \leq 1
\end{aligned}
$$

where $k$ denotes the number of objects and $n$, the number of dimensions, is a normalised version of the differentiation of objects' dimensions $d(i, p)$.

$$
d(i, p)=\sqrt{\left(\sum_{i=1}^{k}\left(z_{i, i}-z_{i, p}\right)^{2}\right)}
$$

where $d_{i p}$ denotes the distance between the objects $i$ and $p$ and $z_{i j} z_{p j}$ the values of dimension $j$ of object $i$ and $p$ respectively.

\section{Research findings and conclusions}

Table 3 presents seven parameters, which were used for comparing the markets. The seven parameters consist of leasing as a share of GDP, leasing as a share of investment, annual growth of leased equipment value, total growth of leased equipment value, share of machinery in total leasing, share of printing machines in total leasing, share of medical equipment in total leasing. Authors realise that the range is limited but this was due to limited availability of data in the Chinese case. These parameters were also divided into four clusters: showing importance of the leasing in the national economy (Cluster I), the growth of the market (Cluster II), the share of machinery in the total market (Cluster III) and share of two different types of machinery, for which data were available (Cluster IV). The calculations were executed for years 2006 and 2007, for which the data were the most extensive. 
Table 3 Market dimensions and their values used in calculations, 2006 and 2007

\begin{tabular}{|c|c|c|c|c|c|c|c|}
\hline \multirow{2}{*}{ \# } & \multirow{2}{*}{$Z_{j}$} & \multirow{2}{*}{ Cluster } & \multirow{2}{*}{ Dimension (parameter) } & \multicolumn{2}{|c|}{ China } & \multicolumn{2}{|c|}{ Poland } \\
\hline & & & & 2006 & 2007 & 2006 & 2007 \\
\hline & $\mathrm{z}_{1}$ & I & Leasing as a share of GDP & $0.32 \%$ & $0.34 \%$ & $2.02 \%$ & $2.71 \%$ \\
\hline & $\mathrm{z}_{2}$ & & $\begin{array}{l}\text { Leasing as a share of } \\
\text { Investment in real terms }\end{array}$ & $0.72 \%$ & $0.79 \%$ & $13.8 \%$ & $16.7 \%$ \\
\hline & $\mathrm{z}_{3}$ & II & $\begin{array}{l}\text { Annual growth of leased } \\
\text { equipment value in real } \\
\text { terms }\end{array}$ & $172.95 \%$ & $121.10 \%$ & $129.12 \%$ & $146.83 \%$ \\
\hline & $\mathrm{z}_{4}$ & & $\begin{array}{l}\text { Total growth of leased } \\
\text { equipment value in real } \\
\text { terms }(2005=100)\end{array}$ & $172.95 \%$ & $209.44 \%$ & $129.12 \%$ & $189.58 \%$ \\
\hline & $\mathrm{z}_{5}$ & III & $\begin{array}{c}\text { Share of machinery in total } \\
\text { leasing in real terms }\end{array}$ & $22.10 \%$ & $25.05 \%$ & $30.09 \%$ & $27.44 \%$ \\
\hline & $\mathrm{z}_{6}$ & IV & $\begin{array}{l}\text { Share of printing machines } \\
\text { in total leasing in real terms }\end{array}$ & $2.01 \%$ & $1.62 \%$ & $2.19 \%$ & $1.62 \%$ \\
\hline & $\mathrm{z}_{7}$ & & $\begin{array}{l}\text { Share of medical equipment } \\
\text { in total leasing in real terms }\end{array}$ & $2.67 \%$ & $2.60 \%$ & $0.98 \%$ & $0.86 \%$ \\
\hline
\end{tabular}

Source: Calculated from data of Research In China, 2008, the World Bank, the Polish Leasing Association and National Statistic Office of Poland

Figure 9 The distance between the markets in different metrics in 2006 and 2007 (see online version for colours)

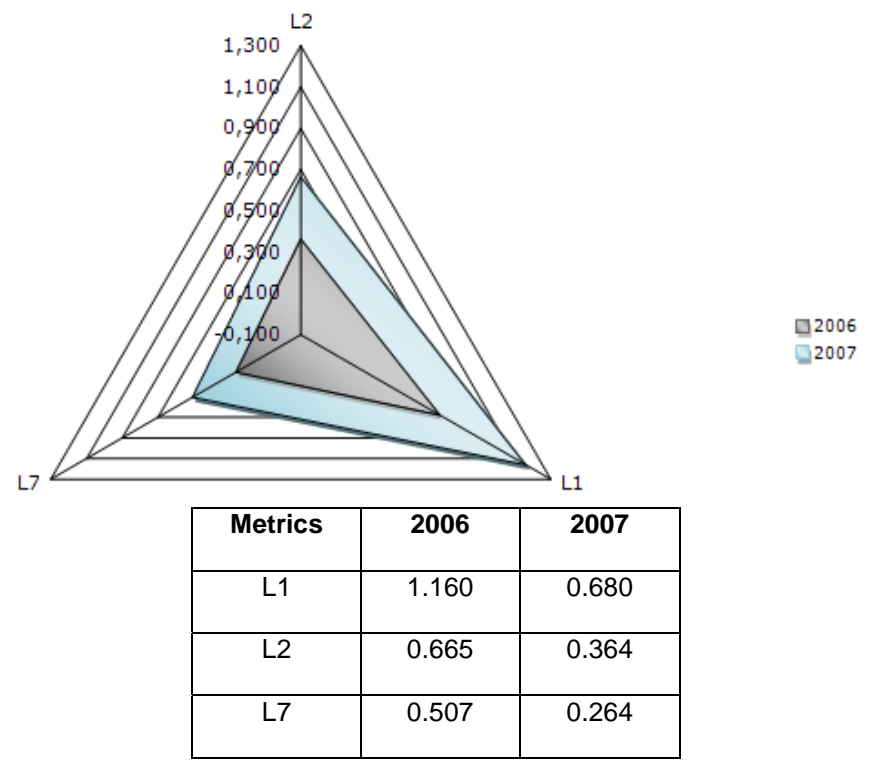


First, the distance measures in particular years 2006 and 2007 were calculated. The results, presented in Figure 9, calculated with all three metrics suggest that the distance between the two markets lowered.

Figure 10 The similarity between Chinese and polish markets counterpart, $d^{*}(i, p)$ measure in 2006 and 2007 respectively (see online version for colours)

\begin{tabular}{|l|c|c|c|c|}
\hline & Cluster I & Cluster II & Cluster III & Cluster IV \\
\hline China 2007 & 0.95988 & 0.91875 & 0.99155 & 0.99565 \\
\hline China 2006 & 0.96692 & 0.83842 & 0.97175 & 0.99574 \\
\hline Poland & 1 & 1 & 1 & 1 \\
\hline
\end{tabular}

Similarity measure $d^{*}(i, p)-2007$
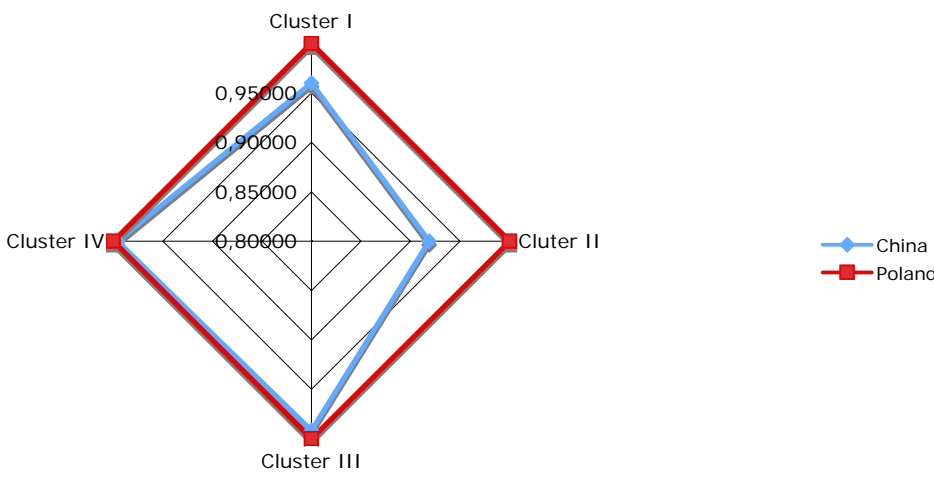

Similarity measure d*(i,p) - 2006

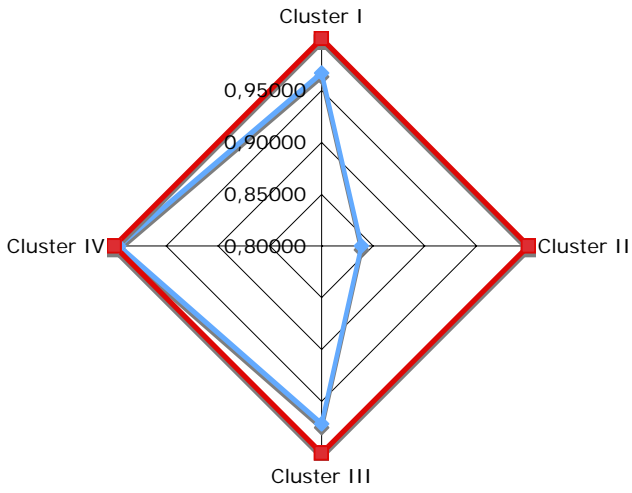

$\rightarrow$ China $\rightarrow$ Poland 
Figure 11 The structures similarity the Chinese and polish markets counterpart, $\mu_{i p}$ measure in 2006 and 2007 respectively (see online version for colours)

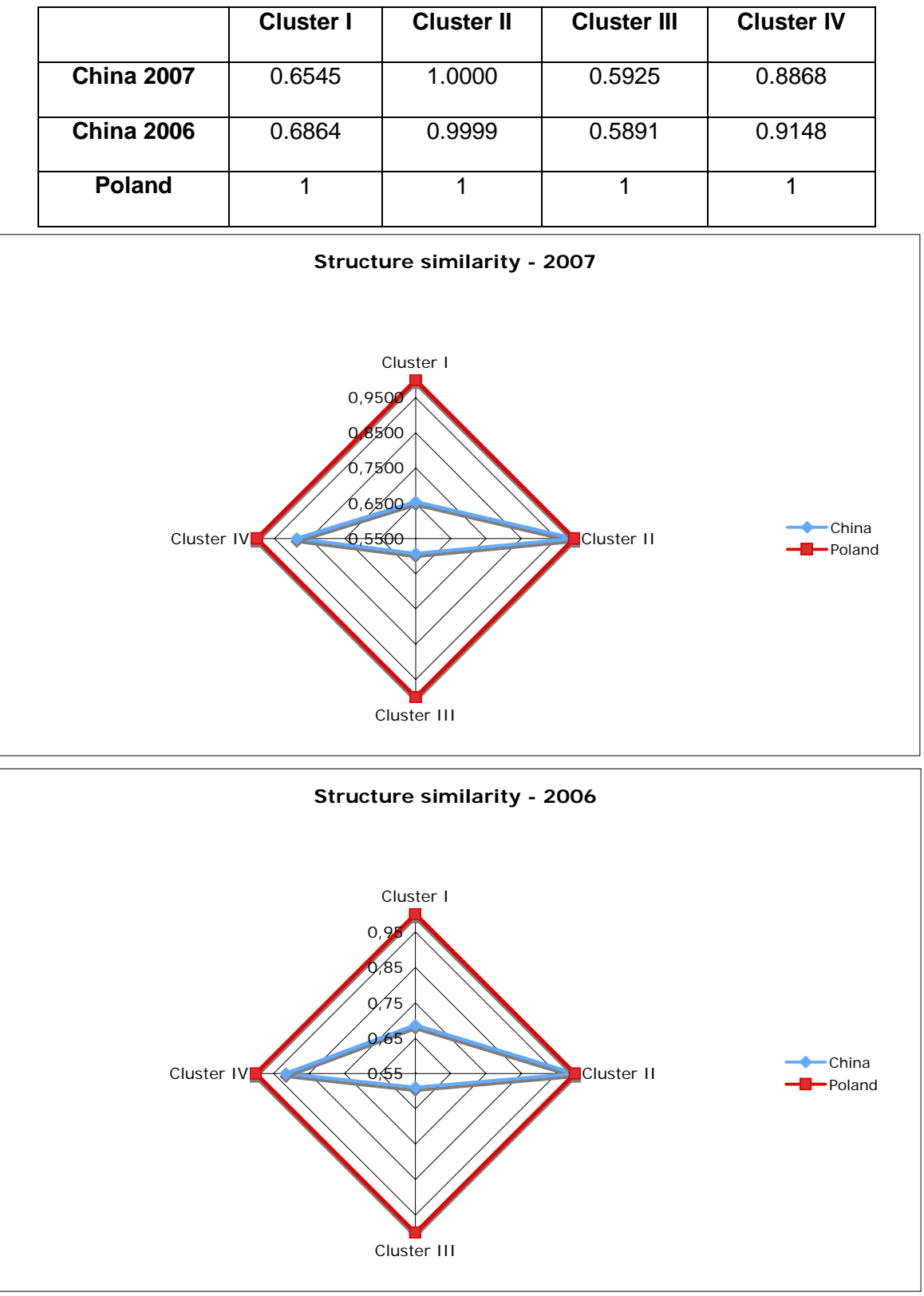

Taxonomy measures were calculated: $d^{*}(i, p)$ for similarity of parameters and $\mu_{i p}$ for structure similarity. For this, clusters defined earlier were used. The calculations as in the case of metrics were executed for years 2006 and 2007 and compared particular years to 
each other. The comparison was done using the Polish market, which is more developed, but without treating it as a blueprint.

The results for similarity measure $d^{*}(i, p)$, which are presented in Figure 10, suggest that the differentiation of parameters decreased (or similarity increased). The highest level of difference could be observed in Cluster II but even here, it fell. The results suggest that both markets share more common features than difference.

The results for structures similarity measure $\mu_{i p}$ are presented in Figure 11. As it can be seen, the markets are more similar when parameters are concerned, which got closer to each other, than in case of the structure: in the period Clusters I and II were totally different on both markets. However, the degree of similarity increased slightly.

This paper provides a comparative study of leasing between Poland and China by examining seven parameters, including leasing as a share of GDP, leasing as a share of investment, annual growth of leased equipment, total growth of leased equipment, a share of machinery in total leasing, a share of printing machines in total leasing, a share of medical equipment in total leasing. While Cluster I parameters show some differences between the two countries in terms of the importance of leasing in the national economy, the results suggest that the two leasing markets share many common features and the differences between the two are not significant in terms of the growth of the market, the share of machinery in the total market and share of two different types of machinery (i.e., printing machines and medical equipment).

In short, the study shows that leasing has been well recognised in Poland and China and they have been used to finance capital investments in the development of their economy. The results could be expanded to other transitional economies with similar economic conditions.

\section{References}

Adedeji, A. and Stapleton, R.C. (1996) 'Leases, debt and taxable capacity', Applied Financial Economics, Vol. 6, No. 1, pp.71-83.

Amembal, S. (2009) Leasing's evolution - a guide to strategist decision making', E.I. Investor, World Leasing Yearbook 2009, pp.56-58, Euromoney Yearbooks, Colchester.

Ayyagari, M., Beck, T. and Demirguc-Kunt, A. (2007) 'Small and medium enterprises across globe’, Small Business Economics, Vol. 29, No. 4, pp.415-434.

Beattie, V., Goodacre, A. and Thomson, S. (2000) 'Operating leases and the assessment of lease-debt substituality', Journal of Banking and Finance, Vol. 24, No. 3, pp.427-470.

Beck, T. and Demirguc-Kunt, A. (2006) 'Small and medium-size enterprises: access to finance as a growth constraint', Journal of Banking \& Finance, Vol. 30, No. 11, pp.2931-2943.

Berger, A.N. and Udell, G.F. (2006) 'A more complete conceptual framework for SME finance', Journal of Bankingand Finance, Vol. 30, No. 11, pp.2945-2966.

Deloof, M., Lagaert, I. and Verschueren, I. (2007) 'Leases and debt: complements or substitutes? Evidence from Belgian SMEs’, Journal of Small Business Management, Vol. 45, No. 4, pp.491-500.

Dipchand, C.R. (1993) Leasing is Gaining Popularity in China, Dalhousie University, Centre for International Business Studies, Halifax, Nova Scotia.

Gao, S. (1995) 'Leasing in Poland - privatization, financing and current problems', European Business Review, Vol. 95, No. 5, pp.31-40.

Gao, S.S. (1999) International Leasing: Strategy and Decision, Ashgate, Aldershot. 
Haynes, P. (2009) 'The world economic crises and how it may affect leasing', E.I. Investor, World Leasing Yearbook 2009, pp.11-12, Euromoney Yearbooks, Colchester.

Graham, J., Lemmon, J.M. and Schallheim, J. (1998) 'Debt, leases, taxes, and endogeneity of corporate tax status', Journal of Finance, Vol. 53, No. 1, pp.131-162.

Hiato, Y. (1986) 'Leasing thrives in China', Beijing Review, Vol. 29, No. 28, p.23.

Huang, H-M. and Yildirim, Y.Y. (2006) Lease Financing, Credit Risk, and Optimal Capital Structure, Working Paper, Syracuse University, Syracuse.

International Finance Corporation (IFC) (1996) Leasing in Emerging Markets, World Bank Publications, Washington, DC

Investor, Euromoney Institutional (2009) World Leasing Yearbook 2009, Euromoney Yearbooks, Colchester.

Investor, Euromoney Institutional (2004) World Leasing Yearbook 2004, Euromoney Yearbooks, Colchester.

Krishnan, V.S. and Moyer, R.C. (1994) 'Bankruptcy costs and the financial leasing decision', Financial Management, Vol. 23, No. 2, pp.31-42.

Lasfer, M.A. and Lewis, M. (1998) 'The determinants of the leasing decision of small and large companies', European Financial Management, Vol. 4, pp.159-184.

Lewis, C.M. and Schallheim, J.S. (1992) 'Are debt and leases substitutes?', Journal of Financial and Quantitative Analysis, Vol. 27, No. 4, pp.497-511.

Martowski, A. (2003) Rozwój leasingu w Polsce, Money.pl [online] http://msp.money.pl/leasing/leasing_w_polsce/historia/ (accessed 25 March 2010).

Michalski, T. and Golebiowska, E. (1996) 'Taxonomy methods in credit risk evaluation', Journal International Advances in Economic Research, Vol. 2, No. 4, pp.409-412.

Nguyen, H.H. and Sharpe, S.A. (1995) 'Capital market imperfection and the incentive to lease', Journal of Financial Economics, Vol. 39, No. 3, pp.271-294.

Research In China (2008) China Financial Leasing Industry Report, Research In China, Beijing.

Sharon, R.E. (1989) 'Leasing update: a range of problems make it difficult area for US companies', The China Business Review, Vol. 16, No. 1, pp.17-19.

SME Department of NDRC (2008) The Situation of SMEs and Non-public Economy in the Past Five Years and the Focus of Year 2008, 11 January, Vol. 1, (448 volumes in total), Briefing [online] http://www.sme.gov.cn/web/assembly/action/browsePage.do?channelID=2 (accessed 5 October 2009).

Szafarowska, M. (2008) Leasing - rozwój, funkcje i cele, from Zwiazek Polskiego Leasingu [online] http://www.leasing.org.pl/o_leasingu/krotka-historia-leasingu (accessed 25 March 2010).

The European Commission (2003) SME's in Europe 2003, Enterprise Directorate-General, Office for Official Publications of the European Communities, Luxembourg.

The World Bank (2009) Country Classification, The World Bank [online] http://go.worldbank.org/ K2CKM78CC0 (accessed 25 March 2010).

Yan, A. (2006) 'Leasing and debt Financing: substitutes or complements?', Journal of Financial and Quantitative Analysis, Vol. 41, No. 3, pp.709-731. 